Artigo original

Hegemonia - Revista Eletrônica de Relações Internacionais do Centro Universitário Unieuro

ISSN: $1809-1261$

UNIEURO, Brasília, número 17, 2016, pp. 4-28.

Recebido em: 17/9/2015

Avaliado em:7/10/2015

Aprovado em: $1 / 11 / 2015$

\title{
Ensaios sobre as Transformações Econômicas da América Latina entre 1800 a 1870: do final do período colonial a consolidação política das novas economias
}

George Henrique de Moura Cunha ${ }^{1}$ e Roberto de Góes Ellery Junior ${ }^{2}$

Resumo: Este artigo visa discutir as questões relativas às transformações econômicas da América Latina nos primeiros anos de sua independência política. O papel das instituições, em grande parte herdada do período colonial, teve impacto de evitar que outros grupos sociais conseguissem ter acesso ao poder. A terra era à base da economia e do controle político. O resultado é a criação de um modelo economia excludente baseado na exportação de produtos primários, de acordo com o principio das vantagens comparativas. Porém, o sucesso deste modelo somente acontecerá após a consolidação da paz interna entre os diversos grupos sociais.

Palavras-chave: História econômica da América Latina; Processo de Independencia; Instituições econômicas e modelo exportador.

Abstract: This article aims discussed issues relating to economic transformation of Latin America in the early years of political independence. The role of institutions, largely inherited from the colonial period, had an impact to prevent other social groups been

Doutor em Economia, docente da Universidade Católica de Brasília.

Doutor em Economia, docente da Universidade de Brasília. 
Artigo original

Hegemonia - Revista Eletrônica de Relações Internacionais do Centro Universitário Unieuro

ISSN: $1809-1261$

UNIEURO, Brasília, número 17, 2016, pp. 4-28.

able to gain access to power. The land was the basis of economic and political control. The result is the creation of an exclusionary model economy based on the export of primary products, in accordance with the principle of comparative advantage. However, the success of this model will only happen after the consolidation of internal peace between the various social groups.

Keywords: Economic history of Latin America; Process of Independency; Economic institutions and export model.

\section{Introdução}

Este trabalho pretende analisar as principais transformações ocorridas na América Latina durante o século XIX, particularmente no período compreendido que antecede a separação política até a consolidação dos novos países independentes. Analisar um período tão amplo e marcado por uma heterogeneidade econômica entre as suas regiões, pode apresentar várias limitações nos resultados encontrados. Da mesma forma isto também pode ser encontrado nas dificuldades de localizar fontes de dados secundárias confiáveis e na homogeneidade destas informações. Por outro lado, as possíveis deficiências nestas informações também possibilitam abrir uma janela para o passado, auxiliando na construção da realidade econômica daquele momento. Este trabalho está dividido em quatro partes: uma introdução; América Latina no final do período colonial; América latina durante o processo de independência política; e conclusões.

2. América Latina no final do período colonial

No final do século XVIII e inicio do XIX, o domínio espanhol na América Latina estava consolidado, da mesma maneira que 0 português. Naquele momento, os dois países se apresentavam como uma metrópole durável, porém subdesenvolvida para os padrões europeus da época. A renda per capita dos países ibéricos eram mais 
Artigo original

Hegemonia - Revista Eletrônica de Relações Internacionais do Centro Universitário Unieuro

ISSN: $1809-1261$

UNIEURO, Brasília, número 17, 2016, pp. 4-28.

baixas que a média da Europa Ocidental. As relações econômicas que se manifestavam na Espanha eram praticamente as mesmas que ocorriam nas colônias americanas, o que produzia um sentimento de identidade entre as duas partes.

"Se as colônias exportavam produtos primários, a Espanha também o fazia. Se as colônias dependiam da marinha mercante estrangeira, também a Espanha dependia. Se as colônias eram dominadas por uma elite senhorial, pouco disposta a economizar e a investir, também o era na Espanha.(LYNCH, 2001. p. 19)"

Porém, havia um tipo de mercadoria que não existia em abundancia na Espanha, mas que era bastante escasso e valioso para o comércio internacional. A conquista da América proporcionou aos dois países europeus o acesso e controla de imensas jazidas destes minerais. Os metais preciosos extraídos da América representavam uma fonte riqueza para o tesouro espanhol ${ }^{3}$.

A relação econômica entre as colônias portuguesas e espanholas com suas metrópoles estava baseando no princípio do exclusivismo colonial. Nesse modelo, cabiam as colônias o fornecimento de sua produção mineral, pecuária e agrícola excedentes. Enquanto, que a metrópole fornecia produtos necessários ao funcionamento das suas economias e proteção contra ameaças externas. Neste conjunto de relações os grandes beneficiados em os comerciantes do porto de Cádiz que centralizavam o comércio com as colônias. Este quadro não se alterava de forma substancial na América Portuguesa, onde o comércio e a navegação do Brasil estavam nas mãos de comerciantes

No final do século XVII, 80\% das exportações da América espanhola eram de metais preciosos (LYNCH: 2001: p. 33). 
Artigo original

Hegemonia - Revista Eletrônica de Relações Internacionais do Centro Universitário Unieuro

ISSN: $1809-1261$

UNIEURO, Brasília, número 17, 2016, pp. 4-28.

lusitanos. Como um sinal da decadência político-militar dos dois países, nas últimas décadas do século XVIII, o comercio colonial ibérico tinha um novo participante: os comerciantes ingleses que forneciam produtos manufaturados.

Os dados sobre atividade econômica sobre este período são escassos e de qualidade inferior. Todavia, eles podem proporcionar uma aproximação da realidade econômica daquele período. Em 1820, quase duas décadas do inicio do processo de independência política, a soma das riquezas produzidas na América portuguesa era praticamente igual ao produto de sua metrópole. Da mesma forma, isto também se manifestava na América Espanhola com a Espanha4. Esta situação acentuava a importância das colônias latinas para suas metrópoles devido ao caráter dependente de suas economias ${ }^{5}$.

A indústria na América Latina antes do processo de independência política era reduzida e até combatida oficialmente em alguns momentos. Não que houvesse naquele momento uma escassez de mercado consumidor, pelo contrário havia uma forte demanda por produtos manufaturados pela economia colonial que não eram satisfeitas pela indústria portuguesa e espanhola. A questão principal era que tanto em Portugal como na Espanha não havia uma indústria

Em 1820, considerando no computo as colônias recém-emancipadas a partir 1809, o PIB da América Espanhola era aproximadamente 12 bilhões de dólares, enquanto que na Espanha isto representava 12,6 Bilhões.

WERNECK SODRÉ (1957) descreve as fragilidades econômicas de Portugal na estrutura produtiva de seu mais valioso produto: os vinhos. Neste setor, os portugueses tinham o controle da produção ao nível de produtor, porém nas demais etapas o controle se fazia por capitais ingleses. 
Artigo original

Hegemonia - Revista Eletrônica de Relações Internacionais do Centro Universitário Unieuro

ISSN: 1809-1261

UNIEURO, Brasília, número 17, 2016, pp. 4-28.

nestes dois países capaz de satisfazer estes mercados, dado a característica predominantemente agrária dos dois países. A grande beneficiada neste caso, era a manufatura inglesa que inundava as colônias americanas com produtos mais baratos e de melhor qualidade.

A chegada de produtos ingleses nas colônias afetou diretamente as manufaturas coloniais existentes, que não conseguiam concorrer. Nas terras espanholas, existiam manufaturas tradicionais chamadas de "obrajes" em Cuzco, Tucumán, e manufaturas têxteis em Puebla e Querétaro que abasteciam os mercados mais próximos, mas que não conseguiam sobreviver à concorrência dos produtos têxteis provenientes da Inglaterra. No Brasil toda a indústria têxtil foi proibida em 1875, sendo permitido produzir tecidos de baixa qualidade para suprir a demanda de escravos e trabalhadores. Porém, após vinte cinco anos foi à vez da Espanha ao proibir a instalação de novas manufaturas, justamente quando a manufatura colonial passou a concorrer diretamente com a protegida manufatura espanhola. 0 controle das duas metrópoles as suas colônias era forte, porém incapaz de conter o crescente contrabando de mercadorias e ideias provenientes de outras regiões.

O enfraquecimento das monarquias portuguesa e espanhola no inicio do século XIX possibilitou que suas antigas colônias conseguissem sucesso no seu processo de emancipação política. O elemento catalizador deste processo foi à conquista da Espanha em 1807 e no ano seguinte a invasão a Portugal. Tais ações enfraqueceram o domínio político destas nações sobre o continente americano. A partir deste momento surgem vários conflitos armados das populações locais contra o controle da metrópole. Tratava-se, portanto, da resposta das sociedades locais aos ideais de liberdade e democracia proclamados pela Revolução Francesa, Haitiana e Norte-Americana, que conseguiram amplo apoio nas elites políticas destes territórios. Cabe destacar que este processo ocorreu de forma quase pacífica no Brasil, e de forma conturbada nas demais colônias. 
Artigo original

Hegemonia - Revista Eletrônica de Relações Internacionais do Centro Universitário Unieuro

ISSN: $1809-1261$

UNIEURO, Brasília, número 17, 2016, pp. 4-28.

No caso Brasileiro, o processo de emancipação política teve início com a chegada da família real portuguesa em 1808, seguindo em 1816 pela transformação da colônia em Reino Unido de Portugal, Brasil e Algarves. Posteriormente, em 1822, a separação ocorre de forma definitiva, com a proclamação de independência por Pedro I, filho do monarca português.

No América Espanhola, os conflitos se seguiram ao enfraquecimento da Casa de Bourbon, seguida por sua deposição e substituição pelo irmão de Napoleão Bonaparte em 1808 desencadearam um processo de revolta da população local contra as tropas invasoras que continuou até 1814 . Neste intervalo de tempo, a elites criollas ${ }^{6}$ aproveitando esta oportunidade iniciam um processo revolucionário por toda América Latina, que resultou na independência de quase toda a região nas três primeiras décadas seguintes.

O poder político e econômico Inglaterra sobre a América Latina aumenta consideravelmente com estes movimentos. Em termos políticos pelo enfraquecimento do Império Espanhol e português após a invasão das tropas de Napoleão Bonaparte. As guerras napoleônicas transformaram o mapa da Europa e mudaram as relações de forças entre as grandes potencias no continente europeu. Durante este conflito, a ocupação francesa sobre o reino da Espanha possibilitou que o controle das colônias espanholas por parte de Madrid fosse reduzida substancialmente, culminando em processo de sucessivos movimentos em favor da independência. Os ingleses não interviram oficialmente neste processo, embora em alguns casos tenham até mesmo enviado tropas para dar suporte militar aos rebeldes americanos. Não importavam os métodos a serem 
Artigo original

Hegemonia - Revista Eletrônica de Relações Internacionais do Centro Universitário Unieuro

ISSN: $1809-1261$

UNIEURO, Brasília, número 17, 2016, pp. 4-28.

empregado, mas sim os meios para evitar que a Espanha mantivesse os mercados de suas colônias fechados às mercadorias inglesas.

3. América Latina durante o processo de independência política

Os países da América Latina após a sua separação política apresentaram poucas transformações em sua estrutura de produção, em relação ao antigo período colonial. Com a emancipação política, pouca coisa havia mudado, os setores principais da economia permaneciam os mesmos: era a mineração de ouro, cobre e prata; seguidas pela agricultura (café, tabaco e açúcar), pecuária (bovina e asinina) e a exploração dos recursos florestais. Em linhas gerais, nada havia mudado. Se antes havia um domínio político, por parte de Portugal e Espanha, agora havia um domínio econômico por parte da Inglaterra?.

Na visão de Donghi (2010, p.32), o papel a ser desempenhado pela região em relação da maior potência colonial de época estava bem claro: "em meio àquele período de grande incerteza, uma coisa ficou clara: a América espanhola emergente era um satélite em um sistema econômico internacional centrado em Londres". Deve-se acrescentar a este quadro, que a independência política de região proporcionou modificações em alguns aspectos da economia colonial. Nesse sentido, Bulmer-Thomas (2010, p.46-48) relaciona dois elementos catalisadores destas transformações: o fim do monopólio 
Artigo original

Hegemonia - Revista Eletrônica de Relações Internacionais do Centro Universitário Unieuro

ISSN: $1809-1261$

UNIEURO, Brasília, número 17, 2016, pp. 4-28.

do comércio externo e a oportunidade de captar recursos no sistema financeiro internacional ${ }^{8}$. Desse modo, o processo de independência da América Latina levou ao fim do exclusivismo colonial nos novos países e ao início de um período de transição para o livre comércio na região. As relações comerciais destas economias com seu maior parceiro comercial obedeciam aos princípios da especialização produtiva para o comércio internacional, preconizadas por David Ricardo9.

Neste conjunto de trocas, proporcionada pela divisão internacional do trabalho, caberia aos ingleses fornecer produtos manufaturados enquanto que as jovens nações latino-americanas abasteceriam produtos primários aos britânicos. Contudo, deve ser ressaltado, que as relações de troca entre as duas regiões era desigual, principalmente pela vantagem conseguida pela Inglaterra como maior produtor de mercadorias manufaturadas, além de ser praticamente a única fonte de recursos externos para os latinos americanos. Além disso, a Inglaterra também era favorecida pelos tratados comerciais assinados como contrapartida ao reconhecimento da Independência que discriminavam os produtos agrícolas latinos em benefícios dos mercados das colônias inglesas ${ }^{10}$.

Dois outros fatores também forma considerados: o desmonte do sistema fiscal e os problemas ocorridos na balança comercial.

Ver Ricardo (1982).

Também não deve ser ignorado o poderio militar dos ingleses. 
Artigo original

Hegemonia - Revista Eletrônica de Relações Internacionais do Centro Universitário Unieuro

ISSN: $1809-1261$

UNIEURO, Brasília, número 17, 2016, pp. 4-28.

O acesso a capitais externos possibilitou um sangue novo para as novas economias, visto que com a desarticulação do poder ibérico e o período revolucionário que sucedeu, manifestou-se uma tendência para a descapitalização das empresas existentes nas antigas colônias. A atividade mineradora, maior fonte de riqueza desta região, não conseguia cobrir a depreciação do seu capital e consequentemente a sua produção. Assim, a oportunidade de modernizar a economia representava uma promessa que poderia traduzir se em bons resultados.

Existe uma máxima na economia que não existe lanche grátis, e os ingleses com toda certeza não tinham vocação para alimentar de forma gratuita a outros povos. Assim, o apoio às colônias rebeldes da América Latina teve o seu custo. Para o reconhecimento de sua autonomia política, foram celebrados diversos tratados comerciais levando à Inglaterra a condição de nação mais favorecida, frente a outros países. Em outras palavras: produtos ingleses teriam nestes mercados impostos de importação bem reduzidos. No caso Brasileiro, o reconhecimento da nossa independência pela Inglaterra em 1824 transformou o país em um Império dependente ${ }^{11}$. Nesse acordo, produtos ingleses pagariam tarifas de importação extremamente baixas sem uma contraposição vantajosa para os produtos brasileiros nos mercados ingleses. Entre os produtos exportados pelo Brasil

Este Tratado era uma ratificação acordo estabelecido em 1810 - Tratado de Comércio e Navegação, quando Dom João VI abriu os mercados coloniais portugueses ao produtos inglês, com uma tarifação menor dos daquelas mercadorias produzidas em Portugal. Os produtos ingleses pagavam uma tarifa de $15 \%$, os portugueses $16 \%$ e os demais países $24 \%$. 
Artigo original

Hegemonia - Revista Eletrônica de Relações Internacionais do Centro Universitário Unieuro

ISSN: $1809-1261$

UNIEURO, Brasília, número 17, 2016, pp. 4-28.

estava: café, açúcar, tabaco, algodão. Assim posto, o acordo de reconhecimento da independência política também levava consigo clausulas lesivas a soberania nacional. Nele, os cidadãos ingleses gozavam de foro privilegiado em território nacional e que somente poderiam ser julgados por tribunais especiais ${ }^{12}$. Nesse cenário extremamente favorável, gradualmente os comerciantes ingleses passaram a dominar o comércio externo do Brasil e demais países, por meio de suas casas comerciais, tanto na forma de importação ${ }^{13}$, como também na forma de exportação de produtos locais ${ }^{14}$. De acordo com Bethel $(2001$, p.587) isto estava bem definido: "De modo geral, porém o comércio de exportação da América Latina, em sua maior parte, estagnou-se no segundo e, em menor grau, no terceiro quarto do século XIX, provocando um desequilíbrio no mercado".

Este cenário, em parte ocorrido na primeira metade do século XIX, era um reflexo dos conturbados movimentos de independência e

Esta era uma prática generalizada pelos Ingleses em todo o mundo, sendo praticada desde a América Latina, no Império Otomano e até na China.

Tecidos, ferragens, cutelaria, porcelana, vidro, pianos, mobília, chapéus e meias. 


\section{Artigo original}

Hegemonia - Revista Eletrônica de Relações Internacionais do Centro Universitário Unieuro

ISSN: $1809-1261$

UNIEURO, Brasília, número 17, 2016, pp. 4-28.

consolidação dos regimes que recém haviam conquistados sua autonomia política, e com os desdobramentos que sucederam, provocaram uma fuga de capitais e destruição de propriedades. Para a maioria das novas nações latinas na primeira metade do século XIX, a constituição de um Estado era uma tarefa a ser executada. Em sua maioria, havia a necessidade de criação de um aparato burocrático para viabilizar a operacionalidade dos governos locais, que muitas vezes partiam de uma estrutura mínima, em geral herdada desde o domínio colonial ${ }^{15}$. Assim posto, a pouca experiência em gestão e a necessidade de construir um aparato administrativo, conduziu as primeiras repúblicas a gastar seus recursos em setores não ligados à produção, e fornecendo poucos haveres na modernização e expansão da produção. Como consequência, saldos negativos na balança comercial foram gerados e a necessidade de financiar estes déficits possibilitou a forte evasão de ouro e prata em direção da Inglaterra.

A fragmentação da América Latina em diversas repúblicas após o período de independência prejudicou o desenvolvimento econômico da região. Isto finalizou a existência de uma união aduaneira que existia de fato em toda América colonial, particularmente em regiões anteriormente controladas pela Espanha ${ }^{16}$. A partir do início deste processo, as novas repúblicas e o Império do Brasil encontraram nas

O Império Brasileiro era uma exceção nesta regra. A vinda da família real portuguesa, em 1808 possibilitou a formação de uma estrutura administrativa, que posteriormente seria aproveitada após a sua independência. 
Artigo original

Hegemonia - Revista Eletrônica de Relações Internacionais do Centro Universitário Unieuro

ISSN: $1809-1261$

UNIEURO, Brasília, número 17, 2016, pp. 4-28.

alfândegas a sua principal fonte de financiamento dos gastos governamentais. As receitas alfandegarias eram extremamente importantes para estes governos, pois a capacidade de tributação era reduzida e limitada às cidades ou nas zonas portuárias. Uma consequência negativa deste processo foi um aumento significativo sobre as tarifas de produtos importados, encarecendo seu preço final para o mercado interno consumidor.

Com a independência política, além das receitas alfandegarias outra fonte significativa esta no sistema financeiro internacional. Assim, em decorrência do sucesso dos processos revolucionários, a autonomia política possibilitou que os países da América Latina obtivessem uma fonte adicional de recursos no mercado internacional, por meio de lançamento de bônus soberanos na bolsa de valores de Londres. Todavia, as dificuldades em administrar estes recursos, em grande parte decorrente de má administração, corrupção e gastos improdutivos, levaram a uma crise da dívida externa nos anos de 1820. Por outro lado, as guerras de independência também cobraram seu preço para a economia, além de desorganizarem a economia oneraram significativamente as escassas reservas cambiais, necessárias para a aquisição e armas, equipamentos e treinamento de suas tropas por oficiais estrangeiros. Este conjunto de fatores, associado à fuga de capitais, proporcionaram a descapitalização das empresas locais impossibilitando os gastos com a depreciação e manutenção das atividades produtivas. Neste caso, isso implicava em alocar escassos recursos para a manutenção das minas e da infraestrutura ${ }^{17}$.

Após a crise de pagamentos das dividas das principais nações latino-americanas na década de 1820, não havia um mercado financeiro local capaz de assegurar recursos para financiar a modernização da economia, com também não havia capitais externos interessados em financiar devido ao alto risco envolvido nestas transações (CHASTEEN: 2001:103). 
Artigo original

Hegemonia - Revista Eletrônica de Relações Internacionais do Centro Universitário Unieuro

ISSN: $1809-1261$

UNIEURO, Brasília, número 17, 2016, pp. 4-28.

Como dito anteriormente, a condição fiscal das novas repúblicas era bastante precária ${ }^{18}$, em decorrência de não haver uma estrutura administrativa consolidada. Assim, era bastante comum que as contas públicas fossem deficitárias e que isto fosse resultado de uma arrecadação insuficiente e de gastos excessivos. A base tributária das novas nações era praticamente a mesma do seu período colonial, neste caso a maioria das receitas decorria do setor exportador, concentrando-se na atividade da mineração. Contudo, uma parte dos novos governos carecia de representatividade, o que transformava o simples ato de tributar, em um grave problema político a ser resolvido pelos grupos políticos que controlavam os novos países. Por outro lado, os novos governos tiveram seus gastos aumentados pelo estabelecimento de exércitos, indenizações aos veteranos de guerra e manutenção das fronteiras.

Se na América Latina a instabilidade política era comum, nos Estados Unidos a situação era totalmente diferente. Desde o início de sua historia republicana os governos dos Estados Unidos sempre estiveram na legalidade eleitoral e uma estabilidade política não vista nas demais partes do continente. Embora, entre 1820 e 1870, os Estados Unidos também passaram por dificuldades politicas e guerras, da mesma forma que o restante da América Latina. A invasão das tropas da Inglaterra em 1812 resultou na queima da sua capital, por um exercito invasor; a guerra contra o México entre 1846 e 1848, que possibilitou aumentar sua área territorial; e a Guerra de Secessão entre 1861 e 1865. Todos estes eventos também poderiam ter prejudicado o desempenho econômico norte-americano em relação aos países europeus mais desenvolvidos. Contudo, todos estes obstáculos não foram suficientes para evitar que a renda per

Ver Bulmer-Thomas (2010, p. 47-48). 
Artigo original

Hegemonia - Revista Eletrônica de Relações Internacionais do Centro Universitário Unieuro

ISSN: $1809-1261$

UNIEURO, Brasília, número 17, 2016, pp. 4-28.

capita dos Estados Unidos se aproximasse da britânica em cinquenta anos.

Após ter a sua independência reconhecida em 1783, à economia dos Estados Unidos consegue maior poder de barganha com a Inglaterra, principalmente ao tornar-se a sua principal fornecedora de matérias primas. Fato este reforçado pelo bloqueio continental decretado por Napoleão Bonaparte a partir de 1806. Antes disso, já havia defensores de um processo de industrialização nativo. Um deles, Alexander Hamilton, Primeiro Secretário do Tesouro Americano, publica em 1791 Report on Manufacutes, cujo conteúdo irá influenciar durante o século seguinte a política de industrial deste país. Em consequência disto, as tarifas de importação são elevadas substancialmente para proteger uma indústria nascente (BRASSEUL, 2011, p. 162-164) ${ }^{19}$.

Após o reconhecimento da independência política pela Inglaterra em 1783, os Estados Unidos constituíram um formidável mercado nacional protegido por barreiras comerciais a concorrência externa ao contrário das outras nações latino-americanas. Em termos geográficos, a extensão territorial deste país foi aumentada com a compra da Luisiana a França em 1803, a anexação do Texas em 1845 e a guerra contra o México em 1846-48, possibilitando a formação de um país com dimensões continentais. Assim, uma indústria interna favorecida pelas barreiras comerciais e um mercado interno crescente ajudaram a economia americana crescer substancialmente.

As diferenças econômicas entre os Estados Unidos e a América Latina ficam cada vez mais explicitas, quando analisado o comportamento

Ao contrário dessa tendência, a América Latina apresentou durante o século XIX tarifas de importação mais baixas que as americanas. 
Artigo original

Hegemonia - Revista Eletrônica de Relações Internacionais do Centro Universitário Unieuro

ISSN: $1809-1261$

UNIEURO, Brasília, número 17, 2016, pp. 4-28.

da renda per capita entre esta nação e os países abaixo da sua fronteira com o México. Entre 1820 e 1870, a renda per capita dos Estados Unidos cresce quase $80 \%$, enquanto que na América Latina isso representou um pouco mais de $24 \%$. Os dados das tabelas 1 e 2 possibilitam ter uma pequena janela de dois períodos distintos: entre 1800 e 1820, que descreve a transição entre o regime colonial e a independência política; e entre $1820 \mathrm{~s} 1850$, que abrange todo o período de consolidação e estabilização dos grupos políticos que controlavam estas nações. Com relação ao período de 1800 a 1820, os dados abaixo possibilitam indicar que, embora a renda per capita fosse muito superior maioria dos países da região, não se verificava ainda um aumento da discrepância entre os Estados Unidos e a Região. Nesta fase, a renda per capita Norte-americana cresceu abaixo da Argentina (7,3\%) e Uruguai (7,3\%) e Cuba $(28,1 \%)$. Embora a renda per capita dos Estados Unidos seja superior ao conjunto dos países da região, os dados disponíveis aparentemente sinalizam que a diferença não esteja crescendo de forma significativa.

Tabela 1: América Latina e Estados Unidos: Renda Per Capita: 1800 e 1870 (1990 International Geary-Khamis dollars).

Pais \ano

1800

USA

Argentina 
Artigo original

Hegemonia - Revista Eletrônica de Relações Internacionais do Centro Universitário Unieuro

ISSN: $1809-1261$

UNIEURO, Brasília, número 17, 2016, pp. 4-28.

Brasil

Chile

626

Colômbia

591

México

836

Uruguai

1.086

Venezuela

415

Cuba

Jamaica

nd

América Latina

nd

Total World

nd 
Artigo original

Hegemonia - Revista Eletrônica de Relações Internacionais do Centro Universitário Unieuro

ISSN: $1809-1261$

UNIEURO, Brasília, número 17, 2016, pp. 4-28.

Fonte: The Maddison-Project,

http://www.ggdc.net/maddison/maddison-project/home.htm, 2013 version.

Contudo, na fase seguinte, de 1820 a 1870, período caracterizado pela separação política da região com Portugal e Espanha, a situação muda radicalmente. Tomando-se por base o ano de 1800, pode-se observar que a renda per capita dos Estados Unidos havia crescido $88,6 \%$ até 1870 . Neste mesmo intervalo de tempo, somente Uruguai $(200,8 \%)$ e Chile $(206,1 \%)$ haviam conseguido um resultado melhor. Quanto aos demais países, também havia se manifestado resultados favoráveis, um bom exemplo disso estava em Cuba que havia crescido um pouco menos $(84,2 \%)$, superando a Argentina $(57,7 \%)$. Das grandes nações latinas, Brasil e México não conseguiram ter um desempenho econômico satisfatório. Embora os dados sejam uma aproximação da realidade, as informações disponíveis sinalizam para uma longa estagnação econômica do Brasil. Em 1870 a renda per capita brasileira era quase igual à verificada em 1800. Em 70 anos, a renda per capita havia crescido somente 4,3\%. Já para o México, a situação era bem mais preocupante, a renda per capita em 1870 era $22,2 \%$ inferior à verificada no inicio do século XIX. 
Artigo original

Hegemonia - Revista Eletrônica de Relações Internacionais do Centro Universitário Unieuro

ISSN: 1809-1261

UNIEURO, Brasília, número 17, 2016, pp. 4-28.

Tabela 2: América Latina e Estados Unidos: Renda Per Capita: 1800 e $1870-(1800=100) \quad(1990$ International Geary-Khamis dollars $)$. Páis \ano 1800

Estados Unidos

100,0

Argentina

100,0

Brasil

100,0

Chile

100,0

Colômbia

100,0

México

100,0 
Artigo original

Hegemonia - Revista Eletrônica de Relações Internacionais do Centro Universitário Unieuro

ISSN: $1809-1261$

UNIEURO, Brasília, número 17, 2016, pp. 4-28.

Uruguai

100,0

Venezuela

100,0

Cuba

100,0

Fonte: The Maddison-Project, http://www.ggdc.net/maddison/maddisonproject/home.htm, 2013 version.

A diferença entre os Estados Unidos e a América Latina começava a ficar cada vez maior. Em 1820, a renda per capita da região era um pouco maior que a metade $(52,3 \%)$, já em 1870 , essa diferença já havia aumentado para um pouco mais que um terço $(36,2 \%)$. Em outras palavras, meio século de atividade econômica haviam sido desperdiçados pelo restante do continente americano. Os dados da tabela 3 são bem claros em mostrar esta situação; Mais alarmante e a situação de Brasil e México que apontavam uma estagnação e uma depressão econômica. Em 1800, a renda per capita de Brasil $(52,7 \%)$ e México $(64,5 \%)$ era um pouco mais elevada que a metade dos Estados Unidos. Já em 1870 os dados eram bem distintos, elas apresentaram uma profunda redução. A renda per capita do México representava um pouco mais que um quarto da Americana $(26,6 \%)$, enquanto que no Brasil isso representava menos de $30 \%$. As repostas para estes resultados levam as caminhos bem distintos para os dois países. Para o Brasil, a solução desse problema passava pela pouca 


\section{Artigo original}

Hegemonia - Revista Eletrônica de Relações Internacionais do Centro Universitário Unieuro

ISSN: $1809-1261$

UNIEURO, Brasília, número 17, 2016, pp. 4-28.

alternativa de produtos exportação e os limitados mercados das mercadorias exportadas pelo Brasil ${ }^{20}$, com relação ao México, o caminho passavam pela estabilidade política da nação.

Tabela 3: América Latina e Estados Unidos: Renda Per Capita em proporção dos Estados Unidos (EUA=100): 1800 e 1870 (1990 International Geary-Khamis dollars)

Pais \ano 
Artigo original

Hegemonia - Revista Eletrônica de Relações Internacionais do Centro Universitário Unieuro

ISSN: $1809-1261$

UNIEURO, Brasília, número 17, 2016, pp. 4-28.

Colômbia

45,6

México

64,5

Uruguai

83,8

Venezuela

32,0

Cuba

38,8

Jamaica

nd

América Latina

nd

Média Mundial

nd 
Artigo original

Hegemonia - Revista Eletrônica de Relações Internacionais do Centro Universitário Unieuro

ISSN: $1809-1261$

UNIEURO, Brasília, número 17, 2016, pp. 4-28.

Fonte: The Maddison-Project, http://www.ggdc.net/maddison/maddisonproject/home.htm, 2013 version e tabulações do autor.

O que poderia ter proporcionado um resultado tão negativo para as terras abaixo do rio Grande ${ }^{21}$ ? Uma boa explicação poderia ser encontrada nos fatores políticos e institucionais. Segundo Przeworski e Curvale (2010, p. 122-123), dois fatores que poderiam explicar este distanciamento: o atraso da América Latina para alcançar a sua independência política e os tumultos ocorridos nestes países que a sucederam.

A instabilidade política que sucedeu ao movimento de independência provocou um colapso nas instituições coloniais prejudicando consideravelmente a capacidade dos novos governos locais para administrar seus conflitos. Em seguida a este processo, deu se a construção de instituições pós-coloniais. Todavia, sua efetivação dependeu da supremacia militar de uma força política ou de um pacto entre os vários grupos dominantes, em outras palavras: uma acomodação política. É importante destacar que os resultados deste consenso político influenciarão diretamente a condução das instituições desta sociedade e consequentemente a forma como a economia será organizada ${ }^{22}$. Desse modo, o respeito ao direito de

Rio que separa a fronteira atual dos Estados Unidos com o México.

As instituições podem ser definidas como um conjunto de regras e normas que determinam os incentivos e as restrições enfrentados pelos indivíduos na sociedade (ROBINSON, 2010, p. 196). 
Artigo original

Hegemonia - Revista Eletrônica de Relações Internacionais do Centro Universitário Unieuro

ISSN: 1809-1261

UNIEURO, Brasília, número 17, 2016, pp. 4-28.

propriedade encoraja o investidor a assumir o risco do investimento, pois o Estado protegerá seu maior patrimônio. Todavia, a grande alternância de poder ocorrida nas cinco primeiras décadas após a independência na maioria dos países latino-americanos, não produziu um clima de confiança ao capital nestes países. Com exceção do Império Brasileiro, cuja estabilidade política foi alcançada com a maioridade do Imperador Pedro II em 1841, a grande maioria dos países da região imperava disputas militares entre os grupos políticos locais.

A herança política colonial interferiu diretamente na construção das instituições pós-coloniais. Durante o período colonial, as sociedades que surgiram eram autoritárias e concentravam o poder nas mãos de uma pequena elite dirigente. Sua dinâmica estava centrada na extração da riqueza da população indígena e na consolidação deste sistema. Após a separação política com a metrópole, as instituições que surgiram eram reflexo do segmento populacional que a controlava. Segundo Robinson (2010, p. 210): "A grande maioria da população não tinha direitos de propriedade garantidos e carecia de incentivos ou oportunidades para entrar em ocupações socialmente desejáveis ou para investir".

$\mathrm{Na}$ América Latina, os grandes proprietários de terras foram responsáveis diretamente pela formação das novas instituições, de modo manter seu controle político e econômico, mantendo alijado deste processo as comunidades indígenas e os pequenos proprietários. Um bom reflexo disso está nas leis que regiam o controle da terra. Ao contrário dos Estados Unidos que privilegiava a posse da terra por pequenos e médios proprietários, na América Latina tratava-se a impedir que isto acontecesse. $O$ acesso a terra foi um problema que se manifestou por toda a América Latina. Durante o processo de independência política, as melhores terras foram absorvidas por aqueles que detinham o poder econômico e político e com ele a posse dos recursos naturais. Neste sentido, a igreja possuía um espaço considerável, pois ela havia conseguido manter seus direitos e propriedades praticamente intactas. A falta de terra livre foi uma das piores heranças do regime colonial, quando vários domínios foram 
Artigo original

Hegemonia - Revista Eletrônica de Relações Internacionais do Centro Universitário Unieuro

ISSN: $1809-1261$

UNIEURO, Brasília, número 17, 2016, pp. 4-28.

dados "de mão beijada" à igreja e a homens de respeito e poder e a sobras erram arrebatadas durantes os conflitos que se seguiram após a independência ${ }^{23}$.

Em 1862, o Governo dos Estados Unidos promulgou uma legislação sobre a posse da terra. O Homestead Act atribuía à posse de uma propriedade com até 160 hectares, ao colono que a cultivasse por cinco anos. Com esta medida, incentivou-se a imigração de europeus e agricultores do leste para as novas áreas agrícolas no oeste americano. Claramente tratava se de um incentivo ao pequeno e médio produtor rural e um importante instrumento de mobilidade social. No Brasil, o acesso a terra pelos imigrantes foi dificultada após a promulgação da Lei das Terras em $1850^{24}$, com forte intuito de foi impedir a maioria dos lavradores de ter acesso à propriedade da terra determinando que a propriedade fosse obtida por meio de compra (Mendes, 2009). Naquele momento, havia uma escassez de mão de obra no campo, em decorrência da expansão da cultura do café na extinção oficial da importação o trafico humano cativo, com a lei Eusébio de Queiróz de 1850.

Segundo Mendes (2009):

"A edição da Lei Eusébio de Queirós e da Lei de Terras, em agosto de 1850, projetou um modelo de longa duração na ocupação territorial brasileira, com decorrências notáveis na

Ver Landes (1998, p.365). 
Artigo original

Hegemonia - Revista Eletrônica de Relações Internacionais do Centro Universitário Unieuro

ISSN: 1809-1261

UNIEURO, Brasília, número 17, 2016, pp. 4-28.

composição fundiária do país. Tratava-se de um desígnio consciente de exclusão debatido às claras, como se viu, no Parlamento do Império. Com o fim do tráfico de africanos, a crise do escravismo entrou na fase aguda, em que a reprodução do sistema passaria a ser paulatinamente atingida pelo avanço da legislação abolicionista. No contexto, as experiências "inovadoras" de contratos de trabalho (parceria, enganchamento) com agricultores europeus iluminaram uma perspectiva em que o acesso à propriedade da terra tornava-se algo distante, fator que contrapunha desfavoravelmente o Brasil aos Estados Unidos, como destino imigratório em larga escala".

Embora as relações entre proprietários de terras e colonos imigrantes tenham melhorado com a adoção de novas leis que impediam maus tratos e que praticamente levavam a condição de escravidão, o principal fluxo migratório de homens livres corria em sentido dos Estados Unidos. Por outro lado, o quadro que sucede ao processo de independência política é bem distinto a dos Estados Unidos. A fragmentação do continente em várias repúblicas faz surgir em algumas delas mercados consumidores bastante reduzidos $\mathrm{e}$ incapazes de sustentar uma indústria nascente frente à concorrência direta das manufaturas inglesas. Assim, o quadro econômico que se manifestava durante o período colonial praticamente permanece inalterado. As novas economias que surgem a partir de 1809 continuavam a depender da agricultura, pecuária e da mineração para a sua sobrevivência como fornecedoras de produtos primários e importadores de bens manufaturados.

Os frutos da economia, porém, continuavam a ser distribuídos da mesma forma que havia se manifestado durante o período colonial. As instituições econômicas que se desenvolveram na região não incluíram toda a população em seus resultados. Pelo contrário, elas beneficiaram uma pequena elite que controlava as minas e os campos. Assim, privilegiou-se a grande propriedade em detrimento das pequenas e medias. Com isso, as chances formação de um mercado interno consumidor estavam limitadas ao pequeno grupo de pessoas 
Artigo original

Hegemonia - Revista Eletrônica de Relações Internacionais do Centro Universitário Unieuro

ISSN: $1809-1261$

UNIEURO, Brasília, número 17, 2016, pp. 4-28.

com poder aquisitivo. Nesse caso, não havia espaço para o desenvolvimento de uma indústria de manufaturas. O modelo agrário exportador era a opção a ser desenvolvida, justificada pelo principio das vantagens comparativas existentes: terras em abundancia e mão de obra barata.

Conclusões

O processo de independência política da América Latina trouxe grandes oportunidades econômicas aos novos países que surgiram após a separação de Portugal e Espanha. Agora a região poderia comercializar diretamente seus produtos com os mercados externos sem a intermediação de terceiros. A instabilidade política manifestada posteriormente em quase toda a região prejudicou sensivelmente 0 crescimento econômico levando ela a um período de estagnação.

As instituições que se formaram a partir da independência eram resultado das mesmas instituições preexistentes, portanto não ocorreram transformações significantes que possibilitassem modificar as oportunidades para as pessoas comuns. Pelo contrário, estas instituições tinham uma característica comum: excluírem a maior parte da sociedade em beneficio de poucos de origem europeia. Um claro exemplo estava no acesso à terra limitado a igreja e aos grandes proprietários. As bases econômicas do continente permaneceram de forma preponderante rural. Eram dos campos e das minas a maior parte das riquezas era gerada.

A partir da década de 1870 , estabilidade política regional, migrações de trabalhadores e novas tecnologias de transporte e comunicação possibilitaram condições para um crescimento elevado na região. 0 modelo de crescimento era baseado na exportação de bens primários, fruto da especialização destas economias nos produtos onde se manifestava uma maior vantagem comparativa. Por outro lado, a região tornou-se um mercado consumidor de produtos 
Artigo original

Hegemonia - Revista Eletrônica de Relações Internacionais do Centro Universitário Unieuro

ISSN: 1809-1261

UNIEURO, Brasília, número 17, 2016, pp. 4-28.

manufaturados, o que não impediu o surgimento de uma incipiente indústria de manufaturas apoiada pelas casas de comércio, grandes exportadores e na mão de obra imigrante.

Os capitais eram escassos e de curto prazo. Eles estavam destinados aos setores mais rentáveis da economia, que em sua maioria estavam ligados às atividades do setor exportador. Desde o inicio das guerras coloniais a Inglaterra influenciava diretamente as economias, tornando-se a principal fonte de divisas. Tal situação Ihe permitia aos ingleses auferir grandes vantagens nas negociações com os governos locais, conseguindo assim colocar a região em sua área de influência.

O domínio do capital inglês foi consolidado na região, com a sua estrutura econômica formada para fornecer insumos para a revolução industrial que tomava curso nos países mais avançados. O que não era uma situação totalmente desfavorável, visto que os preços das commodities estavam em crescimento ao mesmo tempo, que os preços das manufaturas importadas eram reduzidos, em virtude do aumento na concorrência industrial. Desse modo, com condições externas positivas, foi possível criar condições dobrar a renda per capita da região entre 1870 a 1913, de 776 para 1552 dólares. O que representava um resultado extremamente considerável, visto que outras regiões do mundo, como a África e Ásia, o crescimento da renda per capita havia chegado ao mesmo período, a aproximadamente $40 \%$ e $26 \%$, respectivamente. As economias latinas eram dependentes do capital estrangeiro, da mesma forma que outras regiões, pois dependiam do setor externo para horar suas obrigações financeiras e serviço da divida externa. O que a diferenciava a região das outras regiões periféricas, era a sua inserção no comércio internacional e a forma como estas economias estavam atreladas a ordem econômica internacional. Tanto na África, Ásia e América Latina, as grandes potências industriais controlavam direta e indiretamente as economias. Contudo, o que distinguia a América Latina das demais era o carácter da estrutura da sua sociedade. Seus valores eram espelhados com base nas sociedades europeias, o que influenciava diretamente as elites dirigentes e as instituições por elas controladas. 
Artigo original

Hegemonia - Revista Eletrônica de Relações Internacionais do Centro Universitário Unieuro

ISSN: $1809-1261$

UNIEURO, Brasília, número 17, 2016, pp. 4-28.

Bibliografia Consultada

BETHELL, Leslie. A Grã Bretanha e América Latina, 1830 - 1930. In: BETHEL, Lelie (org.). História da América Latina. v. IV. São Paulo: Editora da Universidade de São Paulo/Imprensa Oficial do Estado; Brasília: Fundação Alexandre Gusmão, 2001.

BETHELL, Leslie. O Brasil no mundo. In: CARVALHO, José Murilo. A construção nacional (1830-1998). Rio de Janeiro: Editora Objetiva, 2012.

BRASSEUL, Jacques. História Econômica do Mundo: das origens aos subprimes. Tradução de Helder Viçoso. Lisboa: Edições Texto \& Grafia, 2011.

BULMER-THOMAS, Victor. La historia económica de América Latina desde la independencia. 2a. edición. México: Fundo de Cultura Económica, 2010.

CHASTEEN, John Charles. América Latina: uma historia de sangue e fogo. Rio de Janeiro: Editora Campus, 2001.

CORTÉS-CONDE, Roberto. O Crescimento da Economia Argentina, 1870-1914. In: BETHEL, Leslie (org.). História da América Latina. v.V. Tradução de Geraldo Gerson de Souza. São Paulo: Editora da Universidade de São Paulo/Imprensa Oficial do Estado; Brasília: Fundação Alexandre Gusmão, 2002.

CORTÉS-CONDE, Roberto. Problemas del crescimiento industrial de la Argentina, 1870-1914. Desarrollo Económico. Revista de Ciencia Sociales, Buenos Aires, vol. 3, n 1-2, abril-setembro, 1963.

CUNHA, George Henrique de Moura e ELLERY JUNIOR, Roberto de Góes. Ensaios sobre a economia Argentina no século XIX. Hegemonia (Brasília), v. 13, p. 1-35, 2014. 
Artigo original

Hegemonia - Revista Eletrônica de Relações Internacionais do Centro Universitário Unieuro

ISSN: $1809-1261$

UNIEURO, Brasília, número 17, 2016, pp. 4-28.

CUNHA, George Henrique de Moura. Brasil, Argentina e México: Os Três Reis da América Latina, 1870-1913. Brasília: Universidade de Brasília Tese de Doutoramento, mimeo, 2013.

DONGHI, Tulio Halperín. A economia e Sociedade na América Espanhola do Pós-Independência. In Bethell, Leslie (org.). História da América Latina: da independência até 1870. v.III. Tradução de Maria Clara Cescato. São Paulo: Editora Edusp, 2001.

DONGHI, Tulio Halperin. Dois séculos de reflexões ente os Estados Unidos e a América Latina. In: FUKUYAMA, Francis (org.). Ficando para trás: explicando a crescente distância ente América Latina e Estados Unidos. Rio de Janeiro: Editora Rocco, 2010.

EICHEHGREEN, Barry. A globalização do capital: uma história do sistema monetário internacional. Tradução Sérgio Blum. São Paulo: Editora 34, 2000.

FRANCA, J. A.; CUNHA, George Henrique de Moura. Produtividade têxtil-algodoeira mexicana da era Porfiriana: Uma abordagem comparativa com o Produto Interno Bruto. Espacios (Caracas), v. 35, p. 1-1, 2014.

FURTADO, Celso. Formação econômica do Brasil. Rio de Janeiro: Companhia das Letras, 2007.

HOYOUS, Francisco Martínez. Las independencias. Historia y Vida. Barcelona: Grupo Planeta. N. 536, noviembre 2012, p 32-41.

LANDES, David David. The wealth and poverty of nation. New York: W. W. Norton \& Company, 1988.

LEFF, Nathaniel. Economic devolpment in Brazil, 1822-1923. In: Sthephen Harber (org.). How latim american fell behind: essay on the economic history of Brazil and Mexico, 1800-1914. Stanford, 1997.

LYNCH, Jonh. As origens da independência da América Latina. In Bethell, Leslie (org.). História da América Latina: da independência 
Artigo original

Hegemonia - Revista Eletrônica de Relações Internacionais do Centro Universitário Unieuro

ISSN: $1809-1261$

UNIEURO, Brasília, número 17, 2016, pp. 4-28.

até 1870. v.III. Tradução de Maria Clara Cescato. São Paulo: Editora Edusp, 2001.

MADDSON, Angus. The world economy: Historical statistics. Paris: OECD, 2003.

MENDES, José Sacchetta Ramos; RAMOS, José Aurivaldo; SACCHETTA, Marlene. DESÍGNIOS DA LEI DE TERRAS: imigração, escravismo e propriedade fundiária no Brasil Império. Caderno $\mathrm{CRH}$, v. 22, n. 55, 2009.

PAULO, João Antônio. O processo econômico: a economia brasileira entre 1830 e 1889. In: CARVALHO, José Murilo. A construção nacional (1830-1998). Rio de Janeiro: Objetiva, 2012.

PRZERWORSKI, Adam \& CURVALE, Caroline. A política explica a lacuna entre os Estados Unidos e America Latina. In: FUKUYAMA, Francis (org.). Ficando para trás: explicando a crescente distância ente América Latina e Estados Unidos. Rio de Janeiro: Rocco, 2010.

RICARDO, David. Princípios de Economia Política e Tributação. Tradução de Paulo Sandroni. São Paulo: Abril, 1982.

THE MADDISON-PROJECT. http://www.ggdc.net/maddison/maddisonproject/home.htm, 2013 version. Acessado em 12 de outubro. 2015.

WERNECK SODRÉ, Nelson. O Tratado de Methuen - Domínio inglês em Portugal. Rio de Janeiro: Instituto Superior de Estudos Brasileiros, n², 1957. 